\title{
Educación bilingüe en un contexto CLIL, una propuesta de intervención en Ecuador
}

\section{Bilingual education under a CLIL context, a proposal intervention in Ecuador}

José Luis Andrade Mendoza. ${ }^{1}$, Yajaira Natali Padilla Padilla. ${ }^{2}$ \& Nelly Margarita Padilla Padilla. ${ }^{3}$ Recibido: 20-11-2019 / Revisado: 09-12-2019 /Aceptado: 28-12-2019/ Publicado: 04-01-2020

\begin{abstract}
DOI: https://doi.org/10.33262/cienciadigital.v4i1.1060

English as a foreign language and bilingual education have been happening for a long time in a human history, however, the arrival of twenty century and the development of scientist disciplines like psychology, sociology, linguistics, and psycholinguistics among many others, provided a broad path of development for change and innovation in the field of language teaching. This situation has not stopped, and we are nowadays enjoying the benefits of this evolution and the advances that Information \&Technology and ICT have meant. The main topics covered by this paper are:

What are the main characteristics of CLIL applied in Ecuador? The analysis of the description of bilingualism program based on methodologies of the definition of the CLIL model.

Proposal: Our proposal will be focused on the relevance of a wide training of bilingual teachers. Professors in the nearest time will develop their skills and work in a cooperative way with content teachers and language teachers in order to integrate education to face the reality of non-English speaking countries and prepare bilingual Ecuadorian learners.

Keywords: CLIL, cooperative learning, Ecuadorian bilingual education, bilingual learners.

\section{Resumen}

El inglés como lengua extranjera y la educación bilingüe han estado sucediendo durante mucho tiempo en la historia de la humanidad, sin embargo, la llegada del siglo XX y el
\end{abstract}

\footnotetext{
${ }^{1}$ Escuela Superior Politécnica de Chimborazo, Faculty of Computer Science and Electronics. Riobamba, Ecuador. jose.andrade@espoch.edu.ec

${ }^{2}$ Escuela Superior Politécnica de Chimborazo, Faculty of Computer Science and Electronics. Riobamba, Ecuador.natali.padilla@espoch.edu.ec

${ }^{3}$ Escuela Superior Politécnica de Chimborazo, Faculty of Computer Science and Electronics. Riobamba, Ecuador. npadilla@espoch.edu.ec
} 
desarrollo de disciplinas científicas como la psicología, la sociología, la lingüística y la psicolingüística, entre muchos otros, proporcionaron un camino amplio. de desarrollo para el cambio y la innovación en el campo de la enseñanza de idiomas. Esta situación no se ha detenido, y hoy en día estamos disfrutando de los beneficios de esta evolución y los avances que han significado la información y la tecnología y las TIC. Los principales temas cubiertos por este documento son: ¿Cuáles son las principales características de CLIL aplicado en Ecuador? El análisis de la descripción del programa de bilingüismo basado en metodologías de la definición del modelo CLIL. Propuesta: Nuestra propuesta se centrará en la relevancia de una amplia capacitación de maestros bilingües. Los profesores en el momento más cercano desarrollarán sus habilidades y trabajarán de manera cooperativa con maestros de contenido y maestros de idiomas para integrar la educación para enfrentar la realidad de los países que no hablan inglés y preparar a los estudiantes ecuatorianos bilingües.

Palabras clave: CLIL, aprendizaje cooperativo, educación bilingüe ecuatoriana, estudiantes bilingües.

\section{Introduction}

Teaching and learning a second or third language represents a real challenge, teachers and students find themselves in a wide world of learning, updated approaches and methods transport the academia in an interesting path of knowledge, methods such as "Content and Language Integrated Learning" (CLIL, hereafter) for its meaning in the English language. As CLIL suggests itself, language learning is incorporated to the content which can be covered in all the subjects issued in the educational field, especially in basic education, as it occurs in many bilingual institutions, the content learning is linked with that of the foreign language, where the foreign language is measured and used as a content communication instrument in counterpoint to the study of the specific language. CLIL as a pedagogical strategy is able to study more than two international languages. At this point, CLIL responds to the needs of change and the challenges of the contemporary times.

English as a lingua franca is the most useful language. This means that the interest for CLIL is more than expected. The application of CLIL and the opportunity to motivate the acquisition of English as a second language represents a challenge for both students and teachers.

This article focuses its study on the application, and the benefit that the CLIL model applied to third-year high school students in the CEBI Bilingual Educational School, in the city of Ambato, 
the number of students was 26, with a level B1 according to the Common European Framework of Reference that in English its acronym is CEFR. The intervention proposal involves teachers from different content subjects that focus on a specific one in their curriculum, English language teachers who have the need to work together with majoring teachers, the analysis of the difficulty of adding methodological strategies to combine the teaching style through the foreign language with the mix of a wider range of curricular subjects, which becomes the key that generates opportunities to expand general knowledge to specific subject conducted in a foreign second language.

\section{Theoretical framework}

\section{What is CLIL methodology applied in Ecuador about?}

Biçaku, R. (2011) asserts that the opportunities of increasing the benefits of Clil for teachers are enormous, in the branch of education is well seen for the application of this method specially in non-English speaking countries, where Ecuador that Spanish is the mother tongue English is well acquired for new generations of learners who are getting the bilingualism as a great opportunity of growing.

Marsh (1994) mentions that CLIL represents a combination of content and language where the main purpose is to deliver specific knowledge of the subject by the teacher using a second or third language as the main tool, in the same way, the author makes reference that CLIL embodies the instruction of different topics of study such as social science, art, crafts, in a foreign language.

CLIL is presented as an answer of bilingual educational needs and specially for students who acquire the language of one or more foreign languages through natural forms of communication-related to many specific subjects of study.

The principal objective of the CLIL Model is focused on the application of foreign language as an essential source motivating the oral and written production, and transmission of knowledge, emotions, and concepts. (Dalton, 2007)

\section{Is this educational approach practiced in Ecuador?}

The application of this methodology by English teachers in Ecuador is not so common, probably CLIL model has been applied in an empirical form without any guide, correct training or a specific process, the absence of knowledge about procedures or lack of practice that they are applying it. Many times, language teachers use a particular content to illustrate verbal and / or linguistic problems focused on their bilingual teaching. As a clear example in the application of 
this methodology is the deficiency of authentic material in regular textbooks. That is, in the Ecuadorian education system, the language in the content teaching books through the foreign language, particularly at the elementary basic level, uses a simplified language and, as a result, an unnatural language. CLIL and integrated learning have a wide path because of the distance in the analysis of the inner content. The importance that is given in the learning by content and that of the language of the foreign language is the same, therefore the content is not only by the language and vice versa.

\section{What are the benefits found in a CLIL approach in Ecuadorian scenario?}

The CLIL approach has many advantages, this research provides a brief analysis of the scope of the CLIL teaching and learning model with its main interrelated characteristics. The notorious benefits are taken into account in this study.

- Improvement of time resources in the class. CLIL demonstrates the opportunity to improve language in all the student's skills. Optimus results are evidenced in a short period of time compared to the regular and repetitive model of teaching class. Time represents the most valuable source of a human being. (Abello, Chandler, López, \& Chacón , 2013)

Acquisition of a diverse languages: The practice of different subjects taught in a foreign language is motivated in the integration of content into a target language in order to integrate into the curriculum of the CLIL model. (Ruiz, Sierra, \& Gallardo , 2011)

Motivation to improve CLIL model. Motivation comes from the interest developed from learners in themselves (Intrinsic Motivation) the desire to manage a second language or the curiosity in a foreign langue move bilingual learners in a new field of education. It represents a big challenge and it is vital for teachers to keep that motivation awake, improving their abilities and discovering new strategies in the learning process. (Nakata, 2006)

Significant Contexts. The importance of authentic material in bilingual education is imperative, making the learning more attractive for advanced bilingual learners. When the target language is the principal, the activities are well assimilated for learners, nevertheless, in the case of CLIL the context is completely different since the students are able to manage this approach, and do not find too many problems in studying the foreign language because their reaction is autonomous (Richards \& Rodgers, 2007) 


\section{Application of CLIL Model:}

One of the principal landscapes of a bilingual approach in the improvement of a foreign language is the application of CLIL materials because it promotes the production of inner language material such us texts, books, magazines, etc. In Ecuadorian education the target is focused on the improvement of this approach that assumes those subject teachers who are able to increase the interest in the application of new content in the target language into a second language. Reading and writing in the target language are the most powerful instruments that CLIL develops in learner's skills, it is considered the best chance to promote lexical approaches while those language skills are practiced.

It ought to be very clear that the application of the CLIL model is not a foreign language lesson nor is it a lesson in the contents of the subject transmitted in a foreign language.

The success in a CLIL method is based on the combination of 4 elements that represent the key element of this approach.

Subject Content: The correct acquisition of knowledge, focusing on the interaction of language skills, integrating the essential elements in a foreign language that define the design of the curricula. (Paredes, Henríquez, Zurita, Pinos, Apolinario, \& Campoverde 2018)

Language Communication: The interaction in a target language in order to promote the correct use of the language through different activities.

Learners Cognition: The principal target in the production of cognition in a foreign language was centered on the development of reading and writing skills that connect the information of the subject. (Chen, 2017)

Social Culture: The intensive exposure student knowledge into a different culture, which in this case refers to a target language to be studied. The design of CLIL lesson is focused on the production of speaking skills in order to express ideas, criteria and thought into a second language, where the environment that learners are exposed to, the language skills combination is essential in the assertive application of CLIL model through the foreign language. (Coyle, 1999)

By improving these English language skills, we focus on the following:

Listening, which represents an improvement in the activities of understanding through the ear, is vital for language learning; Reading uses significant material, is the main source of information finally Speaking, focuses on fluency (Barry, 2010). 


\section{Methodology}

A descriptive, non-experimental cross-sectional research was carried out, the technique used was observation and a survey an instrument of evaluation, the process was evaluated by peers prior to its application, guaranteeing this way its reliability.

It was based on the qualitative-quantitative paradigm, First of all, it determined the interest of English-language teachers as well as teachers with specific knowledge of the subject, who have taught the contents without prior knowledge of the CLIL methodology, Second of all, the quantitative part, it was necessary the participation of 26 bilingual education students who worked with authentic material referring to the CLIL methodology, the criteria of each one was essential for data collection and the study of the results.

As background to this research, it must be mentioned that the students who participated actively were chosen randomly, the sample for this study was a total of 26 students, comprising 13 men and 13 women who ranged in ages from 16 to 17, the methodology applied was quantitative and qualitative. In addition, it was necessary for the participation of 4 teachers of the English language and 4 teachers of specific contents.

The place where the research was conducted in the city of Ambato, province of Tungurahua at CEBI Bilingual Educational School which is based on strengthening the knowledge in the English language, by providing international baccalaureate.

To obtain results it was necessary to apply a question bank to the 26 high school students who were the subject of this study, and to 8 teachers from the same bilingual education center, who collaborated with their knowledge in answering the corresponding question bank:

Table 1. Questionnaire for bilingual students

\begin{tabular}{|l|l|l|}
\hline \multicolumn{1}{|c|}{ QUESTIONNAIRE FOR BILINGUAL STUDENTS } & YES & NO \\
\hline 1.- Do you study all the contents of this subject in the English language? & & \\
\hline $\begin{array}{l}\text { 2.- Does the teacher perform activities related to the following aspects: content, } \\
\text { communication, cognition, and culture? }\end{array}$ & & \\
\hline 3.- Do you feel motivated by the bilingual methodology? & & \\
\hline 4.- Do the teachers of specific contents share all their knowledge in the English language? & & \\
\hline 5.- Does the international baccalaureate use English as the only language? & & \\
\hline
\end{tabular}




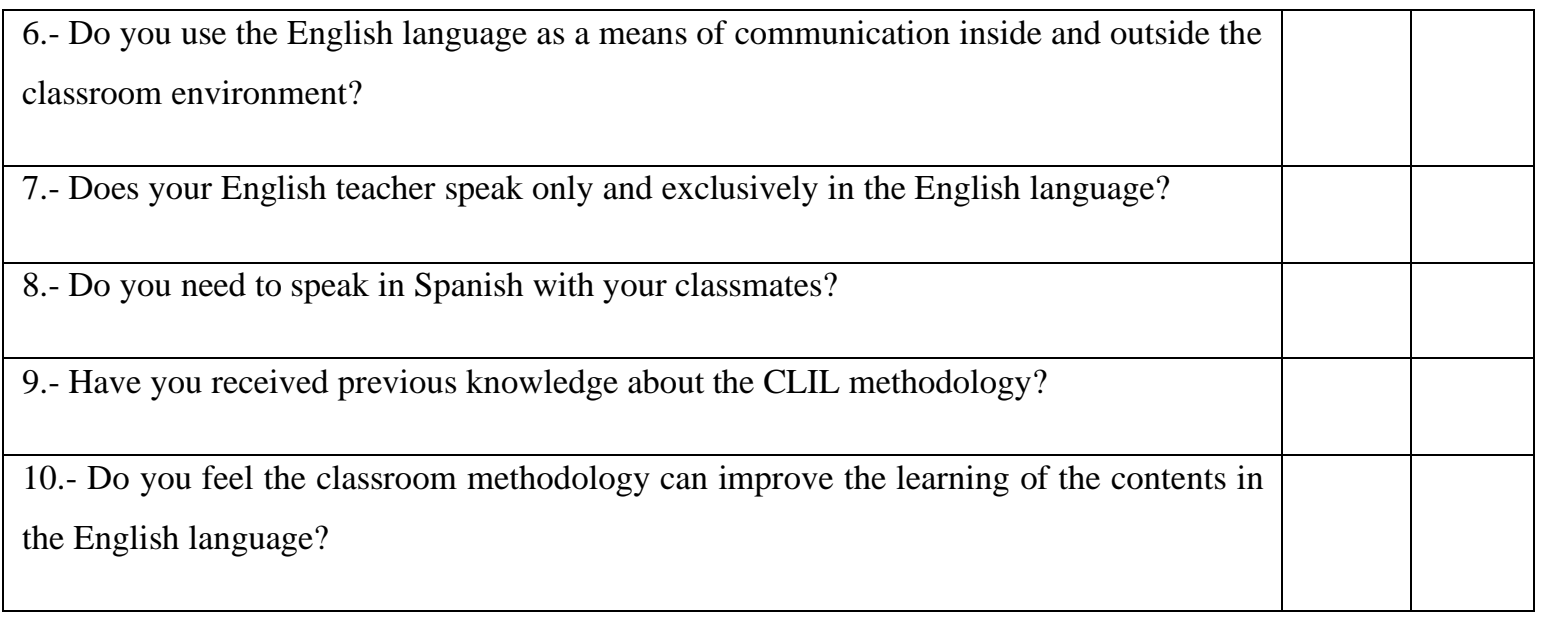

Developed by: The authors

Source: Students of bilingual education from "Educative Bilingual CEBI"

Table 2. Questionnaire for English teachers and general contents

\begin{tabular}{|c|c|c|}
\hline QUESTIONNAIRE FOR ENGLISH TEACHERS AND GENERAL CONTENTS & YES & $\mathrm{NO}$ \\
\hline 1.- Do you prepare your lesson plan in the English language exclusively? & & \\
\hline 2.- Do you prepare your own didactic material or do you have a basic bibliography? & & \\
\hline 3.- Do you have previous knowledge of the CLIL methodology? & & \\
\hline 4.- Do you encourage your students to the bilingual study? & & \\
\hline $\begin{array}{l}\text { 5.- Do your students develop skills in contents, communication, cognition, and } \\
\text { culture through the English language? }\end{array}$ & & \\
\hline
\end{tabular}

Developed by: The authors

Source: Teachers of bilingual education from "Educative Bilingual CEBI"

To deepen the study of the CLIL methodology it is necessary to clear the following questions:

\section{Analysis of results of the CLIL model and the Ecuadorian education system}

According to the results obtained in question 1 about the study of the contents in the subject through the English language, 20 students corresponding to $76.9 \%$ answered yes and 6 students corresponding to $23,1 \%$ answered no.

Regarding question 2 on whether the teacher performs work in relation to content, communication, cognition and culture, 18 students equivalent to $69.2 \%$ answered that these contents are covered, and 8 students representing $30.8 \%$ mentioned they are not. 
In question 3 about motivation 13 students, it means 50\% answered yes, they feel interested in the bilingual modality and the other $50 \%$ answered no.

In question 4 about teachers of specific content who share all their knowledge in English, 25 students representing $96.2 \%$ answered yes and only 1 student equivalent to $3.8 \%$ answered that they do not.

In question 5, 100\% of the manifested stated that in international baccalaureate English is used as the only language.

In question 6 about the use of the English language as a tool of communication inside and outside the classroom, 19 students, equivalent to $73.1 \%$, affirmed that they do it, and 7 students corresponding to $26.9 \%$, they answered that they do not.

In question 7, 18 students, equivalent to $69.2 \%$ claimed that the English language teacher speaks only and exclusively in the English language and 8 students who are $30.8 \%$ said they do not feel agree.

In question 8 about the need to speak in Spanish with their peers $15(57.7 \%)$, students said they do, and $11(42.3 \%)$ said they do not.

In question 9, 100\% of learners mentioned that they have not received previous knowledge of the CLIL Methodology.

With regard to question 10, 24 students, representing the $92.3 \%$ feel that the methodology in the classroom can improve the learning of English language content and only 2 that are $7.7 \%$ feel that this methodology does not help them improve their learning.

Graph 1. Questionnaire for bilingual students

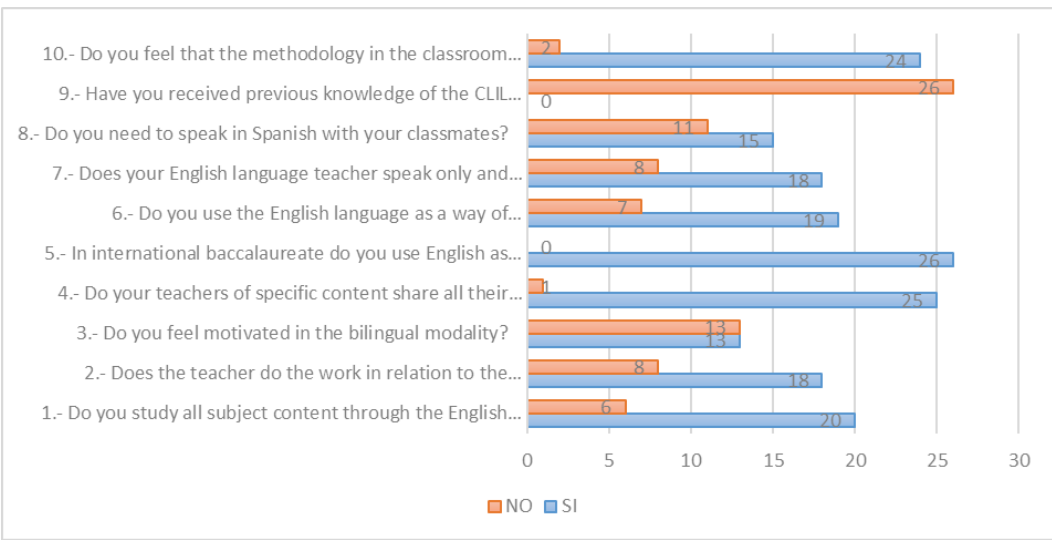

Developed by: The authors

Source: Students of bilingual education from "Educative Bilingual CEBI" 
The following results were obtained in the survey of the 8 English language teachers:

In question 1 about class planning, 6 teachers (75\%) do it exclusively in English and 2 teachers (25\%) do not use only the English language.

Regarding question 2, $50 \%$ of teachers have a basic bibliography to develop their teaching material and the other $50 \%$ answered they do not since the teaching material is made exclusively by them.

In relation to question 3 about previous knowledge of the CLIL methodology, only 2 teachers (25\%) said they do, and 6 teachers $(75 \%)$ said no.

In question 4, 100\% of teachers stated that they encourage their students in the bilingual study.

In question 5, 6 teachers (75\%) state that their students develop skills in content, communication, cognition and culture through the English language, and 2 teachers (25\%) mention that they do not.

Graph 2. Questionnaire for English teachers and general contents

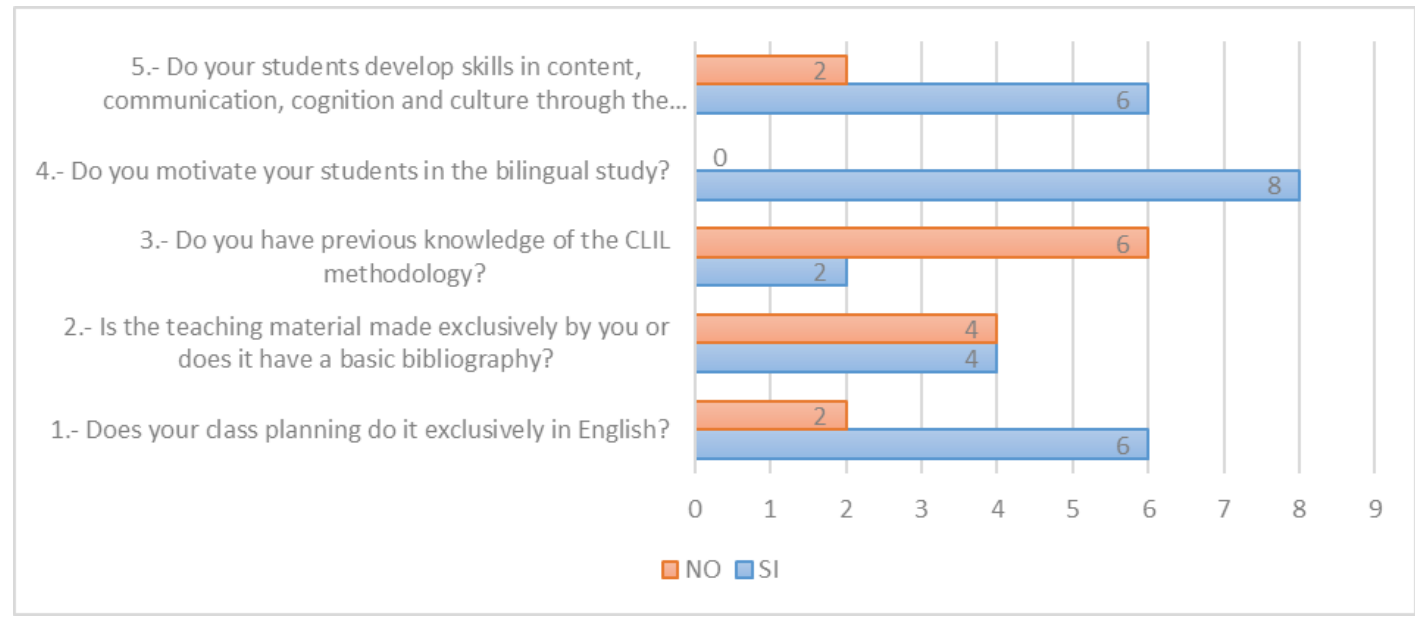

Developed by: The authors

Source: Teachers of bilingual education from

\section{"La Unidad Educativa Bilingüe CEBI"}

There is no doubt that the approach of the future on teaching English as a foreign language is CLIL since it includes a wide variety of teaching practices. According to Oonk, Maslowski and Van der Werf (2011), this method focuses on language acquisition, the creation of autonomous impressions, ideas, and skills, as well as additional linguistic, dialect, morphological and semantic language. The influence of CLIL in European countries influenced its good command of a foreign 
language with an optimal preparation of studies that begin in elementary school and in secondary schools in the entire world.

Ecuador demonstrates its interest in the implementation of CLIL in its teaching model of a foreign language since the Ecuadorian population has the need to transmit content in groups of different linguistic and cultural backgrounds; According to the General Regulation in the Organic Law of Intercultural Education (hereinafter, LOEI for its acronyms in Spanish), there is a specific regulation in the CLIL acquisition model and the development of bilingual programs focused on the acquisition of content and language in its Ministerial Agreement No. 0052-14 that makes inference of the bilingual process in different educational programs in "Basic General Education (2 to 10) and Unified General Baccalaureate (1 to 3)".

Ibarra, A. (2019) in her thesis research mentioned that "the General Regulation to the Organic Law of Intercultural Education (LOEI) published in the second supplement in the official register 417 on March 31, 2011, based on Ministerial Agreement No. 0052-14, Article 111 establishes that educational institutions such as public and private education, may include the qualification of Bilingual in their name", it means that any education center must demonstrate at least forty percent of their workload in the foreign language of the educational institution. (MINEDUC, 2015)

Under this statement, Ecuadorian legislation mentions in its Ministry of Education (2017), that the current curriculum is focused on a CLIL approach based on language, where the content is used for the practice of useful and meaningful language (Met, 1999). The incorporation of critical thinking skills in the Ecuadorian curriculum has been inspired by Bloom's taxonomy and the development of communicative language skills in a CLIL model, where critical thinking skills assist as the instrument to implement $4 \mathrm{C}$ (content, culture, communication, and cognition) that represents the essential conceptualization of the CLIL model (Coyle, 2007).

\section{Research Projections}

\section{Proposal}

The proposal for this research is to motivate researchers, educators, content teachers, and language teachers to improve their capacity to teach a second language. Referring to CLIL model, there are two main actors to consider: Bilingual learners; those who work harder every day when learning becomes intuitive, and need the guidance of their teachers; and bilingual teachers who are the responsibilities that make it all possible in a bilingual context. The request is focused if it is 
accessible to apply CLIL in a regular class? Does the effort and time put into practice represent a good advantage in the teacher's lives? Does the CLIL model help bilingual teachers? Do you need specific studies in the application of this approach? Are teachers able to apply the model in their regular classes? what would be the benefits in an Ecuadorian scenario? Definitely, CLIL is evidenced that has special work to be applied, the effort and time involve considerable practice. The collaboration between subject teachers (Content teachers) and language teachers is elemental for better working. CLIL approach needs a variety of class activities and teaching design, time that it is spent with double effort. The material applied in the class required the collaboration of both teachers This process represents a specific time and hard working with assertive management of sources. In a few words, the present study demonstrates that all teachers can apply CLIL model and do not necessarily require specialized studies, just it is required cooperative work and good relations between them and of course a lot of perseverance in order to accomplish this additional work.

\section{Conclusions}

This proposal is connected to teachers and students. We strongly believe that it is more fruitful to invest in teachers for their specific preparation by imparting unique knowledge in the desired language, thereby an appropriate promotion of the CLIL learning model. It is essential to promote the real progress of teachers and students who are interested in this modern model of education, because most people look for different acquisition content strategies in a target language and, of course, language acquisition is every time more attractive for teachers with knowledge about CLIL and possibly to integrate that knowledge proudly in our country.

\section{Referencias Bibliográficas}

Abello, C., Chandler, P., López, M. D., \& Chacón, R. (2013). Bilingual and Multilingual Education in the 21st century. Ontario: Multilingiual Matters.

Barry, M. (2010). Success international English Skills IGCSE. New York: Cambridge University Press.

Biçaku, R. Ç. (2011). CLIL and teacher training. Procedia - Social and Behavioral Sciences, 15, 3821-3825. Retrievet from https://doi.org/10.1016/j.sbspro.2011.04.379

Chen, G. (2017). Combining TBLT and CLIL to teach English and Chinese in Foreign Language $\begin{array}{lllll}\text { contexts } & \text { (Universidad } & \text { Retrieved from }\end{array}$ 
https://doi.org/10.14201/gredos.135766

Coyle, D. (1999). Supporting Students in Content and Language Integrated Learning Contexts: Planning for Effective Classrooms. London: Centre for Information on Language Teaching and Research.

Dalton, C. (2007 ). Discoruse in Content and Language Integrated Learning (CLIL) classrooms. Philadelphia: John Benjamins Publishing .

Ibarra, A. (2019). TECHNIQUES USED BY BASIC EDUCATION TEACHERS OF THE $N^{o} 4$ AREA (Pontificia Universidad Católica de Ecuador). Retrieved from https://repositorio.pucese.edu.ec/bitstream/123456789/1967/1/IBARRA

QUIROZ ADRIANA PATRICIA.pdf

Met, M. (1999). Content-based instruction: Defining terms, making decisions. Washington: The National Foreign Language Center.

Ministry of Education Ecuador (2017). https://educacion.gob.ec/. Retrieved from https://educacion.gob.ec/wp-content/uploads/downloads/2016/03/ EFL.pdf

Nakata, Y. (2006). Motivation and Experience in Foreign Language Learning. Switzerland: Peter Lang.

Oonk, H., Maslowski, R., \& Van der Werf, G. (2011). Internationalisation in Secondary Education in Europe. Netherlands: Information Age Publising Inc.

Paredes, R., Henríquez, E., Zurita, R., Pinos, V., Apolinario, O., \& Campoverde, M. (2018). New Curriculum in Ecuador. In Journal of Chemical Information and Modeling (First, Vol. 1). Retrieved from https://doi.org/10.1017/CBO9781107415324.004

Richards, J., \& Rodgers, T. (2007). Approaches and Methods in Language teaching. New York: Cambridge University Press.

Ruiz, Y., Sierra, J. M., \& Gallardo , F. (2011). Content and Foreign Language Integrated Learning Contributions to Multilingualism in European context. New York: Peter Lang.

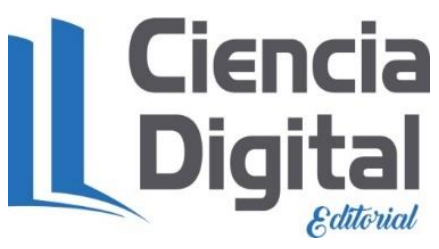




\section{PARA CITAR EL ARTÍCULO INDEXADO}

Andrade Mendoza, J. L., Padilla Padilla, Y. N., \& Padilla Padilla , N. M. (2020). Educación bilingüe en un contexto CLIL, una propuesta de intervención en Ecuador. Ciencia Digital, 4(1), 321-333. https://doi.org/10.33262/cienciadigital.v4i1.1060

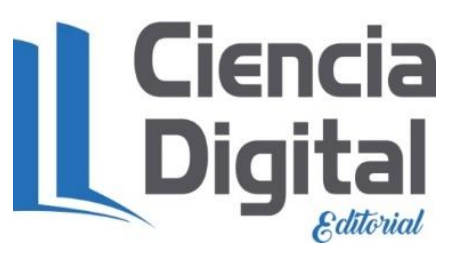

El artículo que se publica es de exclusiva responsabilidad de los autores y no necesariamente reflejan el pensamiento de la Revista Ciencia Digital.

El artículo queda en propiedad de la revista y, por tanto, su publicación parcial y/o total en otro medio tiene que ser autorizado por el director de la Revista Ciencia Digital.
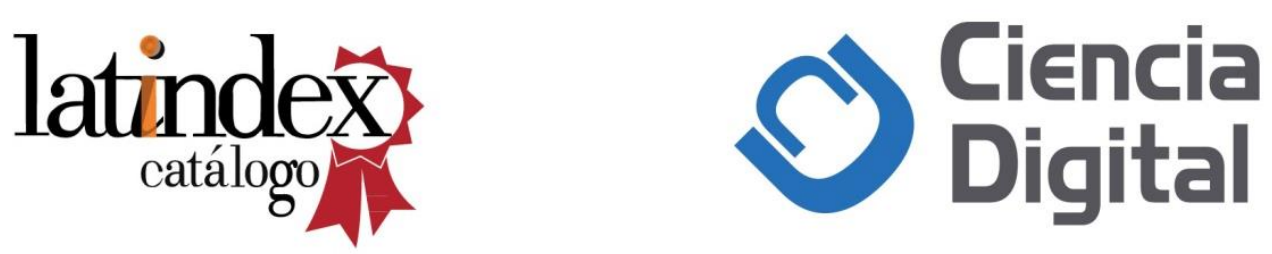